\title{
EXPERIMENTAL AND NUMERICAL STUDIES OF CONTINUOUS COMPOSITE BEAMS TAKING INTO CONSIDERATION SLAB CRACKING
}

\section{BADANIA DOŚWIADCZALNE I NUMERYCZNE ZESPOLONYCH BELEK CIĄGŁYCH Z UWZGLĘDNIENIEM ZARYSOWANIA PŁYTY*}

\begin{abstract}
This paper presents the results of studies conducted on composite beams which function as models of representative bridge deck elements subjected to bending. The adopted type of load and the resulting strain of the analysed system correspond to operating conditions. The subject of the studies was steel and concrete composite beams with fasteners in the form of pins. Experimental tests of girders were carried out on a near real-life scale under the static load corresponding to the operating load. The obtained results were used to build a numerical model using the finite element method. The non-linear concrete damage plasticity model was used to describe the concrete and the elastic-plastic body model was adopted to describe the steel. Two concrete slab-steel beam connection methods were analysed: a continuous connection and a spot connection using rigid fasteners. Next, the validation of the numerical model was performed. A comparison of the selected operating characteristics of the tested systems was made on the basis of the adopted criteria.
\end{abstract}

Keywords: composite beam, experimental studies, numerical modelling, concrete damage plasticity model, Abaqus, operating load, operating lifespan.

\begin{abstract}
Praca prezentuje wyniki badań belek zespolonych, stanowiących modele reprezentatywnych elementów ustrojów nośnych obiektów technicznych (mostów) poddawanych zginaniu. Przyjęty rodzaj obciażenia oraz powstałych deformacji rozpatrywanego uktadu odpowiada warunkom eksploatacyjnym. Przedmiotem rozważań byty belki zespolone typu stal-beton z tącznikami w postaci sworzni. Przeprowadzono badania eksperymentalne dźwigarów w skali zbliżonej do rzeczywistej pod obciażeniem statycznym odpowiadajacym obciażeniu eksploatacyjnemu. Otrzymane wyniki postużyty do budowy modelu numerycznego przy wykorzystaniu metody elementów skończonych. Do opisu betonu wykorzystano nieliniowy model betonu plastycznego ze zniszczeniem, natomiast do opisu stali przyjęto model ciała sprężysto-plastycznego. Przeanalizowano dwa sposoby połaczenia płyty betonowej z belka stalowa: połaczenie ciagłe oraz połaczenie punktowe wykorzystują sztywne taczniki. Następnie przeprowadzono walidację przygotowanego modelu numerycznego belki. Dokonano porównania wybranych właściwości eksploatacyjnych badanych ustrojów, w oparciu o przyjęte kryteria.
\end{abstract}

Stowa kluczowe: belka zespolona, badania eksperymentalne, modelowanie numeryczne, model betonu plastycznego ze zniszczeniem, Abaqus, obciązenie eksploatacyjne, trwałość.

\section{Introduction}

Special requirements with regard to the theory of composite structures and their creative shaping make them one of the most interesting solutions for load-carrying structures in the construction technology. The constituent parts of the cross section are made of materials with different Young's moduli, which interact with each other through the use of fasteners. These elements are joined to maximise both their strength properties and operating characteristics with respect to their location within the feature.

The greatest benefits are currently visible in the application of steel-concrete composite structures [24]. These are mainly used in bridge construction but are also used in other areas of the construction industry, especially in the industrial construction [16].

The importance of the issue of cracking in the context of continuous composite structures is still a topic of discussion. Although the structure safety is not compromised in any way, its operating lifespan is significantly affected. Non-structural cracks can cause damage to insulation and - in the long - cause corrosion of the reinforcement, as well. Therefore, it must be remembered that the operating lifespan of the structure is one of the basic assumptions in the design process and it significantly affects the adopted design solutions and materials [26]. The feature's operating lifespan is maintained when the structure fulfils its function within a given time both for its load-bearing capacity (ultimate limit states) and serviceability (limit states related to the reduction of cracks, stresses and deflections). The correct structure design ensures that it is fit for purpose for at least the period of expected operating lifespan. The requirements for the bridge structure operating lifespan are particularly high, though. In accordance with [26], bridges are classified as the S5 design category (class), which means the approximate design lifetime of at least 100 years.

Nowadays, in order to meet the increasingly stringent operating lifespan criteria, the design phase for composite bridges should take into account non-structural concrete cracking and the change of its stiffness between the cracks

$\left({ }^{*}\right)$ Tekst artykułu w polskiej wersji językowej dostępny w elektronicznym wydaniu kwartalnika na stronie www.ein.org.pl 
[28] in the ultimate limit state and serviceability limit state. Concrete cracking affects the stiffness of the composite section and can cause an overload of the steel section. The change in the stiffness causes redistribution of excessive bending moments along the length of the continuous beam. The problem of the behaviour of the composite structure with the cracked concrete slab is complicated and not fully explored. For this reason, the stiffness of the concrete in tension in often overlooked in the design of civil engineering structures. This approach leads to an irrational assessment of the load-bearing capacity and serviceability of the composite structure, which causes a reduction in the lifetime of the feature [36].

This problem also occurs in the case of the existing steel bridges, which are often subjected to treatments aimed at increasing their operating lifespan [34]. The strengthening or modernisation of many road bridges made of steel often involves replacement of the wooden bridge deck for a concrete one that interacts with the grid or the main girders. Also in the railway bridges with the travel way directly on the structure, a ballast pan is added in the form of a concrete deck interacting with the steel grid or, for instance, the main truss girders. Then, some composite elements are subjected to tensile stresses that cause the formation of cracking and consequently - the reduction of the structure service life [7].

Therefore, in recent years there has been a significant increase in the research devoted to issues of the mechanical behaviour of the continuous composite beams $[2,20]$ in the context of shaping the operating lifespan and reliability of the feature, in particular at the structure dimensioning stage [41]. These studies usually focused on the strength limit of the entire composite section $[13,14]$ or its individual parts $[3,10]$, the concrete slab cracking $[12,17]$ and the methods of controlling the cracking width $[32,33]$, the symptoms of the damage [5], the application of compression [6], as well as the joining flexibility $[19,35]$.

In relation to the cited studies, this paper determined the impact of the concrete between the cracks in a continuous composite beam slab in tension (the so-called tension stiffening) on the issue of the operating lifespan of the structure in relation to the operating loads. For this purpose, experimental tests on almost real-life scale bridge girders [23] and numerical studies using the finite element method were conducted.

\section{Experimental tests on composite beams.}

\subsection{Test pieces}

The subject of the experimental tests were continuous doublespan composite beams characterised by the parameters shown in Fig. 1. The overall length of each test piece was $7.00 \mathrm{~m}$, including the support spans of $2 \times 3.00 \mathrm{~m}$.
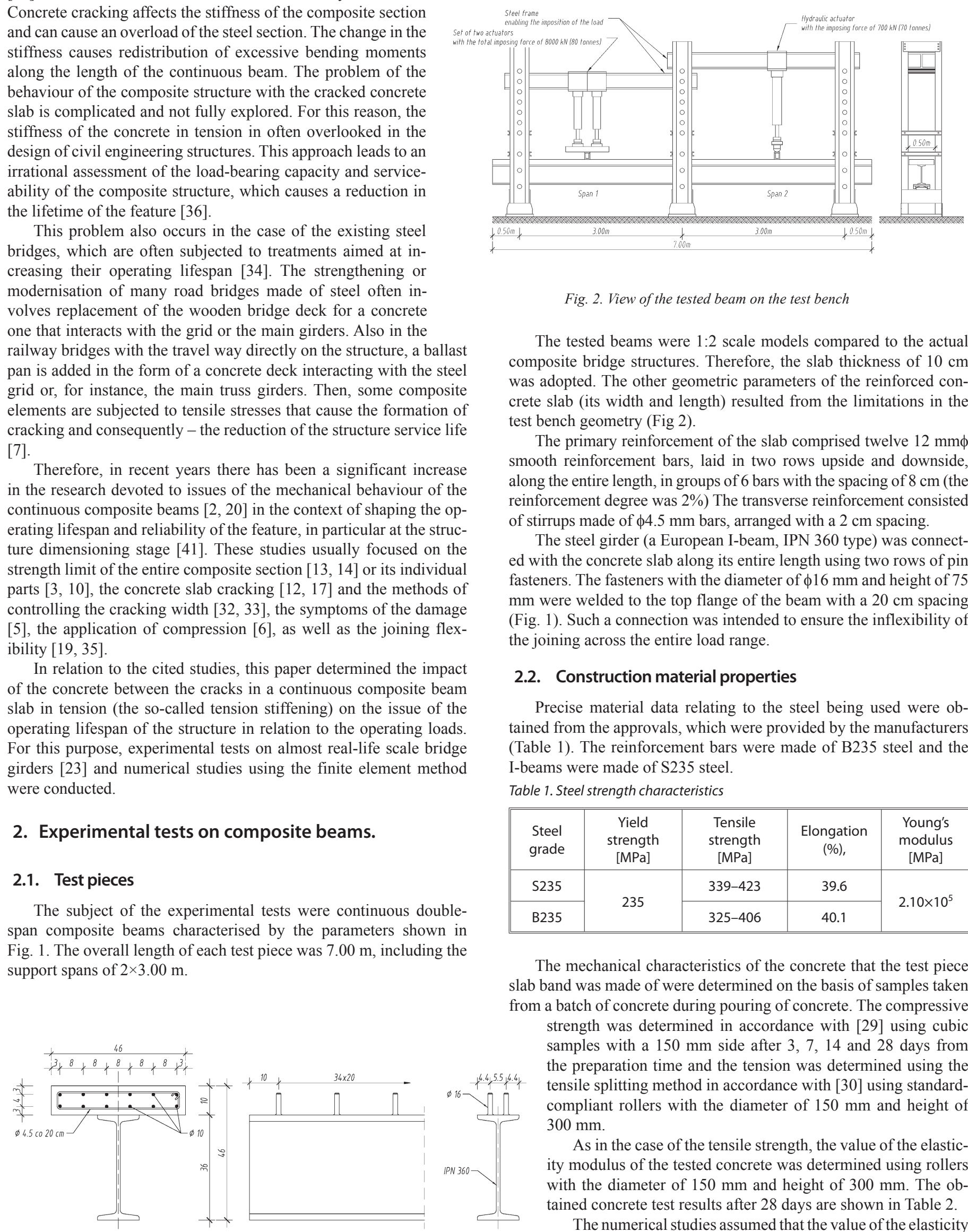

Fig. 2. View of the tested beam on the test bench

The tested beams were 1:2 scale models compared to the actual composite bridge structures. Therefore, the slab thickness of $10 \mathrm{~cm}$ was adopted. The other geometric parameters of the reinforced concrete slab (its width and length) resulted from the limitations in the test bench geometry (Fig 2).

The primary reinforcement of the slab comprised twelve $12 \mathrm{~mm} \phi$ smooth reinforcement bars, laid in two rows upside and downside, along the entire length, in groups of 6 bars with the spacing of $8 \mathrm{~cm}$ (the reinforcement degree was $2 \%$ ) The transverse reinforcement consisted of stirrups made of $\phi 4.5 \mathrm{~mm}$ bars, arranged with a $2 \mathrm{~cm}$ spacing.

The steel girder (a European I-beam, IPN 360 type) was connected with the concrete slab along its entire length using two rows of pin fasteners. The fasteners with the diameter of $\phi 16 \mathrm{~mm}$ and height of 75 $\mathrm{mm}$ were welded to the top flange of the beam with a $20 \mathrm{~cm}$ spacing (Fig. 1). Such a connection was intended to ensure the inflexibility of the joining across the entire load range.

\subsection{Construction material properties}

Precise material data relating to the steel being used were obtained from the approvals, which were provided by the manufacturers (Table 1). The reinforcement bars were made of B235 steel and the I-beams were made of S235 steel.

Table 1. Steel strength characteristics

\begin{tabular}{||c|c|c|c|c||}
\hline $\begin{array}{c}\text { Steel } \\
\text { grade }\end{array}$ & $\begin{array}{c}\text { Yield } \\
\text { strength } \\
{[\mathrm{MPa}]}\end{array}$ & $\begin{array}{c}\text { Tensile } \\
\text { strength } \\
{[\mathrm{MPa}]}\end{array}$ & $\begin{array}{c}\text { Elongation } \\
(\%),\end{array}$ & $\begin{array}{c}\text { Young's } \\
\text { modulus } \\
{[\mathrm{MPa}]}\end{array}$ \\
\cline { 1 - 3 } S235 & \multirow{2}{*}{235} & $339-423$ & 39.6 & \multirow{2}{*}{$2.10 \times 10^{5}$} \\
\cline { 1 - 1 } B235 & & $325-406$ & 40.1 & \\
\hline
\end{tabular}

The mechanical characteristics of the concrete that the test piece slab band was made of were determined on the basis of samples taken from a batch of concrete during pouring of concrete. The compressive strength was determined in accordance with [29] using cubic samples with a $150 \mathrm{~mm}$ side after 3, 7, 14 and 28 days from the preparation time and the tension was determined using the tensile splitting method in accordance with [30] using standardcompliant rollers with the diameter of $150 \mathrm{~mm}$ and height of $300 \mathrm{~mm}$.

As in the case of the tensile strength, the value of the elasticity modulus of the tested concrete was determined using rollers with the diameter of $150 \mathrm{~mm}$ and height of $300 \mathrm{~mm}$. The obtained concrete test results after 28 days are shown in Table 2.

The numerical studies assumed that the value of the elasticity modulus in compression is equal to the value of the modulus in

Fig. 1. Tested beam parameters 
Table 2. Concrete test results after 28 days

\begin{tabular}{|c|c|c|c|c|c|}
\hline \multicolumn{2}{|c|}{$\begin{array}{l}\text { Compressive } \\
\text { strength } \\
\text { [MPa] }\end{array}$} & \multicolumn{2}{|c|}{$\begin{array}{c}\text { Tensile strength } \\
\text { [MPa] }\end{array}$} & \multicolumn{2}{|c|}{$\begin{array}{l}\text { Young's modulus } \\
\text { [MPa] }\end{array}$} \\
\hline Samples & Avg. & Samples & Avg. & Samples & Avg. \\
\hline 70.24 & \multirow{3}{*}{70.15} & 3.77 & \multirow{3}{*}{3.82} & $43.41 \times 10^{3}$ & \multirow{3}{*}{$43.19 \times 10^{3}$} \\
\hline 70.19 & & 3.89 & & $43.08 \times 10^{3}$ & \\
\hline 70.02 & & 3.79 & & $43.09 \times 10^{3}$ & \\
\hline
\end{tabular}

slab in the span section. In turn, in the case of the support section, because of the method in which the test pieces were supported, the strain gauges were mounted on the bottom of the web, right above the bottom flange.

Beams were loaded gradually by applying incremental concentrated forces in four full load-unload cycles. The first cycle was always carried out in the range from $0 \mathrm{kN}$ until the appearance of the first crack (120 and $230 \mathrm{kN}$, correspondingly). In the next cycles, the force was increased by approx. $200 \mathrm{kN}$ until the maximum assumed load was reached. The maximum value was reached in each cycle by the gradual increasing of the force, introducing intermediate load tension [39]. It was also assumed that the compression strain corresponding to the maximum compressive strength is $\varepsilon_{\mathrm{cl}}=0.0026$ and ultimate compression strain is equal to $\varepsilon_{\mathrm{cul}}=0.0030$.

\subsection{Load implementation and measured quantities}

The tests of the beams were carried out in cooperation with the Kielce University of Technology and Bridge Testing Centre (Kielce branch) being part of the Research Institute of Roads and Bridges.

Test pieces were placed between the steel frame posts that prevented the beam from moving away from the central position if the beam slid from one of the bearings (Fig. 2). The location where the external loads were applied was chosen in such a way that the values of the induced bending, span and support moments were similar to each other and there were negative moment zones in the test piece which caused tensioning of the upper fibres of the reinforced concrete slab. Thus, the load in the form of two concentrated forces was located at the distance of $175 \mathrm{~cm}$ on each side of the central support (Fig. 3).

The forces were applied to the top surface of the slab using the structure (a small steel beam with a washer) that distributed them on a band that was transverse to the axis of the $100 \mathrm{~mm} \mathrm{x}$

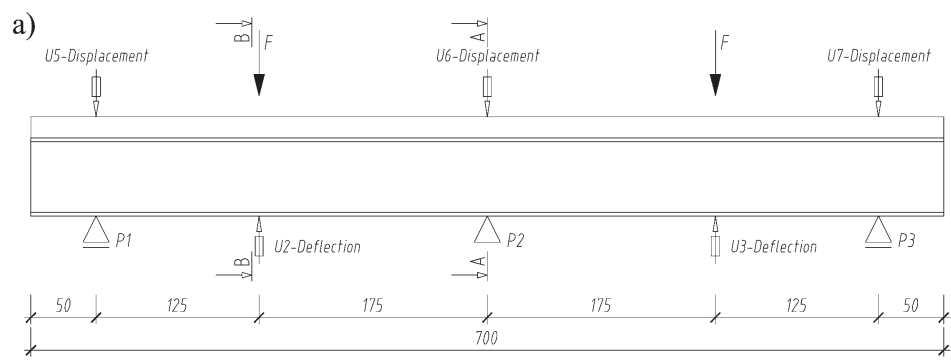

b)

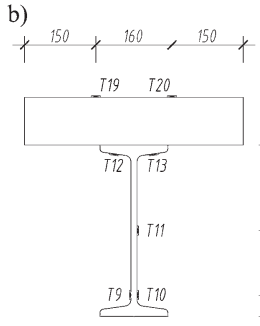

c)

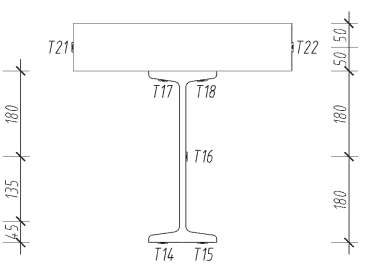

Fig. 4. Distribution of the measurement point: a) side view, b) support section, c) span section

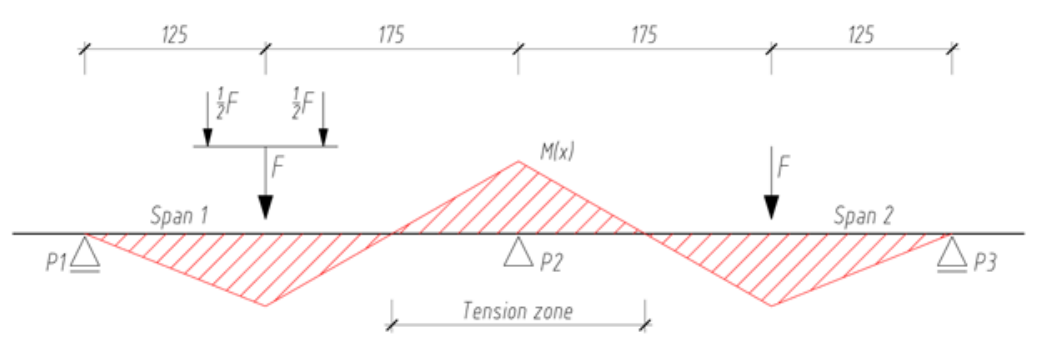

Fig. 3. Load diagram for the tested beams - the distribution of moments along the length of the beam

$460 \mathrm{~mm}$ beam. The load induced in span 1 via two hydraulic actuators was additionally transferred via a traverse beam.

The tests measured the displacement of the composite girder, the strain in the steel beam and the composite reinforced concrete slab (in two sections: above the support - in the so-called negative moment zone, and in the span - i.e. in the so-called positive moment zone). The crack propagation was measured, as well. Stress was measured in the steel girder using electro-resistant strain gauges and in the reinforced concrete slab using paper strain gauges. The location of the strain gauges was chosen in such a way so as to obtain the readings of the desired quantities in points considered to be the most sensitive based on the operating criteria - Fig 4. Because of the structure that distributed the load on the transverse band, on the entire width of the slab, the strain gauges were attached to the side faces of the values. The load increase rate was on average $10 \mathrm{kN} / \mathrm{min}$. The load range corresponded to the operating load of the assumed system (elastic work range).

\subsection{Results of the experimental tests}

Two composite beams were tested. The results were recorded on a continuous basis in each cycle and the resulting cracks were measured after reaching the intended load. The test determined the number of cracks, the direction of their development and their reach - key parameters for the analysis of stiffness and the estimation of deflections and redistribution of bending moments, especially with regard to the elastic range (operating loads) in continuous systems.

The next part of the paper presents the results of selected quantities in the graphical form or as table summaries. Markings of supports, measuring points, etc. were adopted in accordance with Fig. 3 and Fig. 4.

\subsubsection{Crack propagation in time}

During the crack propagation studies, all the measurements were made at each load level. In accordance with the earlier assumptions, the main area of observation was the tension zone. In order to obtain a more complete picture of the state of cracking in the composite beams, measurements were made in the compression areas. In the central support zone, due to the impossibility of accessing the slab side planes at the width of $\sim 30 \mathrm{~cm}$, the measurements were made on the upper surface of the slab or at its axis, correspondingly. In com- 
pression zones, though, due to the traverses used in the spot where the load was being transferred, the access to the upper surface of the slab was hampered on a $10 \mathrm{~cm}$ band.

Table 3 presents a summary of the number of cracks in each tested beam, depending on the value of acting force and the induced bending moment (span and support moments). When calculating the number of cracks, only cracks that stretched across at least $50 \%$ of the width of the slab were taken into account and two shorter cracks situated on opposite edges of the slab and located in the same section were treated as one crack.

Table 4. Average spacing between the cracks above the intermediate support

\begin{tabular}{||c|c|c|c|c||}
\hline \multirow{2}{*}{$\begin{array}{c}\text { Beam } \\
\text { no. }\end{array}$} & $\begin{array}{c}\text { Length of the } \\
\text { cracked seg- } \\
\text { ment }\end{array}$ & $\begin{array}{c}\text { Num- } \\
\text { ber of } \\
\text { cracks }\end{array}$ & $\begin{array}{c}\text { Average dis- } \\
\text { tance between } \\
\text { cracks }\end{array}$ & $\begin{array}{c}\text { Theoretical avg. } \\
\text { crack spacing in } \\
\text { accordance with } \\
\text { PN-EN [27] }\end{array}$ \\
\cline { 2 - 5 } B1 & 104 & 9 & 10.8 & [cm] \\
\hline B2 & 102 & 9 & 10.4 & \multirow{2}{*}{16.6} \\
\hline
\end{tabular}

In the so-called positive moment zone, the crack arrangement was typical of the compressed slab. A crack appeared along the longitudinal beam axis - in both directions from the location where the load was applied - with the length between $120 \mathrm{~cm}$ and $180 \mathrm{~cm}$, depending on the beam. Such cracking confirms the presence of tensile stresses perpendicular to the axis of the beam being bent.

The last test related to the crack propagation in time was the measurement of the crack spacing, which was conducted within the axis of the slab. Table 4 presents the measured values of the average crack spacing on segments where cracking occurred and the average design distance between cracks determined in accordance with [27].

The final crack spacing was approx. $11 \mathrm{~cm}$ and was smaller than the spacing of the transverse bars $-20 \mathrm{~cm}$. This means that the cracks were not generated by each of the transverse reinforcement bars in the continuous beams within

Although the final number of cracks in all beams was similar, it was observed that their formation and development was different every time. For the B2 beam, the initiating crack was formed at the load corresponding to the cracking moment, and a crack appeared in the $\mathrm{B} 1$ beam only when the force of $230 \mathrm{kN}$ was applied, which induced the bending moment that was twice as large.

In each beam, a different cracking morphology was observed, which only confirmed that the cracking mechanism is very complex. However, it was observed during the tests that the cracks propagated always from the slab edge towards its axis, but did not connect with cracks progressing from the other side in each beam. It was also observed during the tests that after the application of the maximum load, the number of cracks did not increase and only an increase in their width occurred.

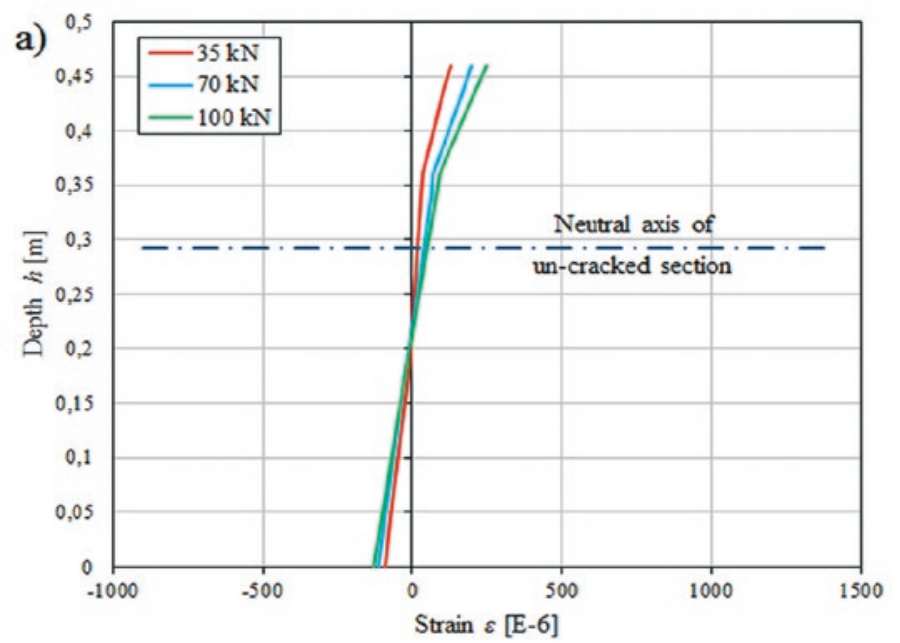

the segment where stresses exceeded the concrete tensile strength.

It may also be noted that the value of the average crack spacing in accordance with the relations included in Eurocodes is approx. $35 \%$ $-37 \%$ higher than the measured value. This confirms only that the proposals presented in the standard $[28,40]$ which make it possible to computationally determine the impact of the concrete slab cracking in the negative moment zone on the operating lifespan of the structure requires further refinement and experimental verification, especially in the context of the continuous beams in the operating conditions.

\subsubsection{Results of the strain (stress)}

Strain gauge sensors, used to check the convergence of the results, were distributed symmetrically to the axis of the girder. The obtained

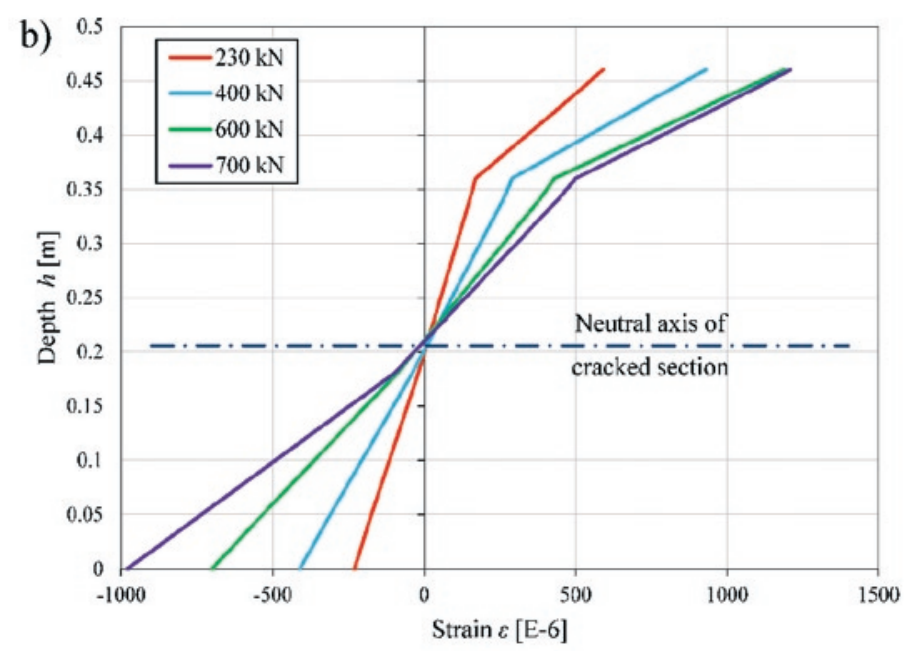

Fig. 5. Strain distribution in the B1 beam support section: a) prior to cracking, b) after cracking 

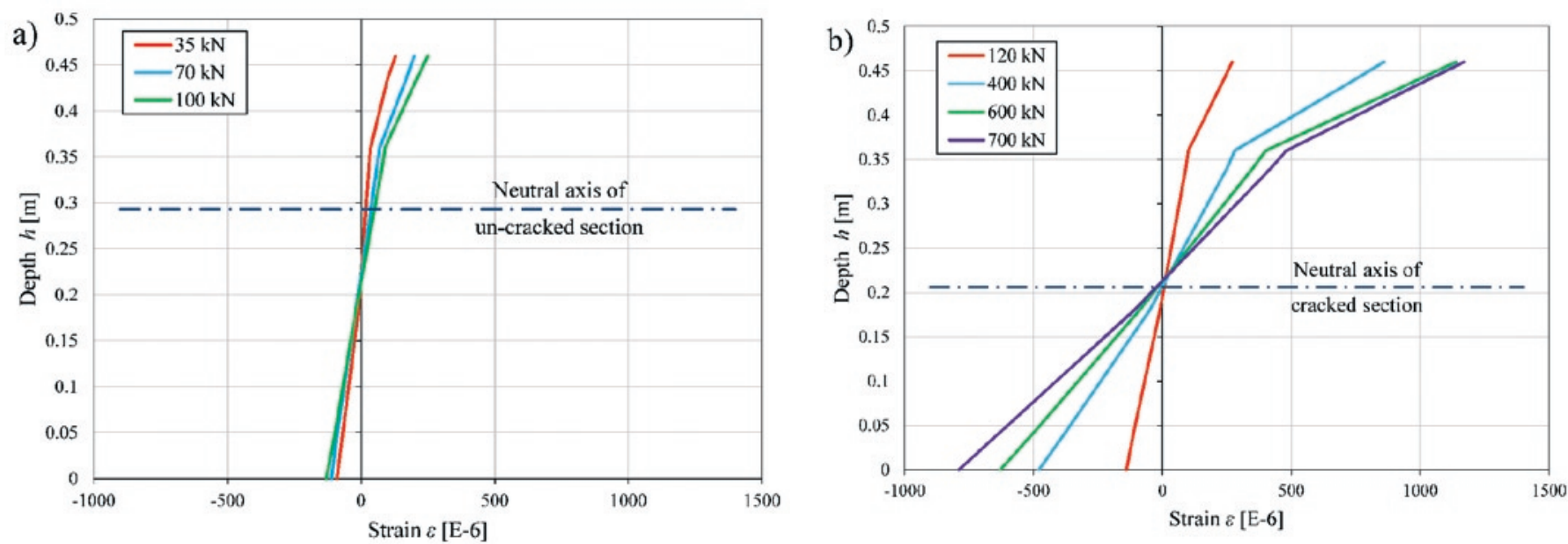

Fig. 6. Strain distribution in the B2 beam support section: a) prior to cracking, b) after cracking
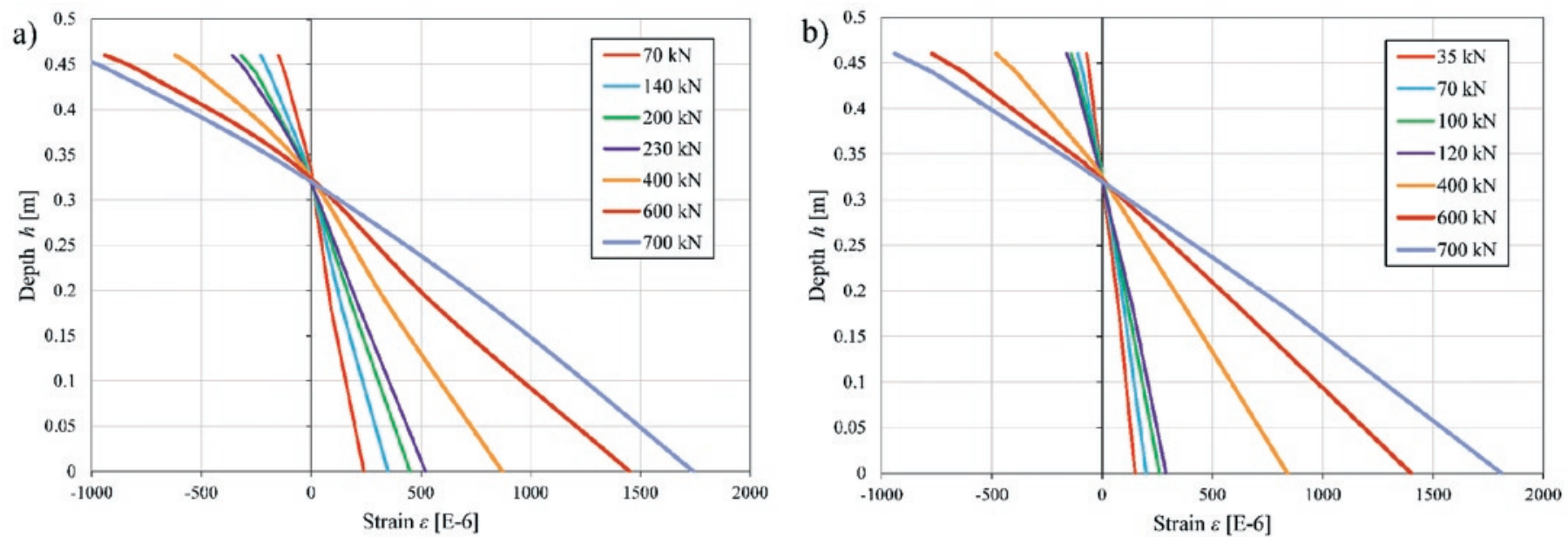

Fig. 7. Strain distribution in the span section: a) $B 1$ beam, b) B2 beam
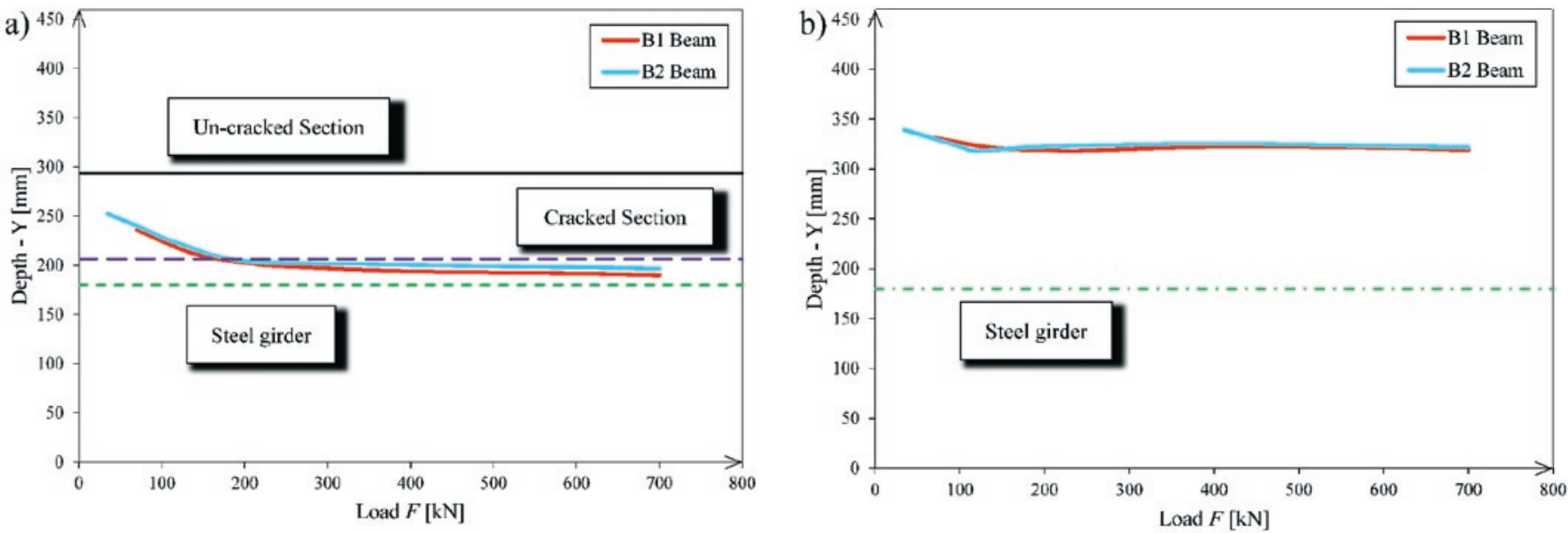

Fig. 8. Change in the position of the neutral axis: a) section $A-A, b)$ section $B-B$

results were presented in the form of diagrams. For each tested item, the average strain value was calculated while applying a particular loading force.

The results of the strain confirm the good convergence between the test pieces (Fig. 5, Fig 6, Fig. 7). With the operating load values applied, all the beams worked in a full elastic range during the test. The maximum strain values did not exceed 1800E-6. The obtained strain measurement values also made it possible to determine the actual location of the neutral axis.

In all the tested beams in the span section, the initial loading phases (forces between $70 \mathrm{kN}$ and $230 \mathrm{kN}$ in the $\mathrm{B} 1$ beam and forces between $35 \mathrm{kN}$ and $120 \mathrm{kN}$ in the $\mathrm{B} 2$ beam) showed a gradual decline in the position of the neutral axis and its subsequent stabilisation approx. at the level of $320 \mathrm{~mm}$. On the other hand, in the case of the support 


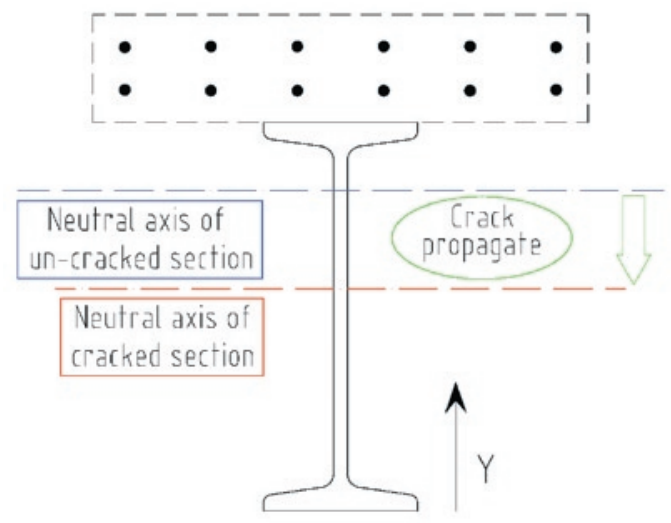

Fig. 9. The impact of the slab cracking on the change in the position of the neutral axis in the support section

section, the decline in the neutral axis position occurred throughout the entire range of the assumed load. At low values of the forces being applied, this phenomenon progressed rapidly. However, after reaching the slab cracking inducing force, the movement of the neutral axis towards the axis of the cracked section progressed gradually (Fig. 8).

The actual position of the neutral axis of the composite section is located, therefore, between the designated axes of the cracked and non-cracked sections. At the time of the occurrence of the new cracks, the neutral axis moved towards the neutral axis of the section with stabilised cracking (Fig. 9).

Using the measured strain magnitudes in the section, the local curvature of the test pieces was determined, which made it possible to determine the stiffness of the section.

The analysis of the behaviour of the steel-concrete composite beams can use only instantaneous stiffness. This results, in particular, from the concrete properties which change in operation, depending on the degree of stress ratio and flexibility of the bonds between the steel part and the concrete part.

Starting from the known relationship between the instantaneous stiffness $B$ and the curvature $\chi$ :

$$
\chi=\frac{1}{\rho}=\frac{M}{B},
$$

where:

$\rho$ - the radius of curvature,

and the relationships that exist between the bending moment $M$ and the stress $\sigma$ :

$$
\sigma=\frac{M \cdot y}{J}
$$

where:

$J$ - the geometrical moment of inertia of the effective composite section,

and the stress $\sigma$ and the strain $\varepsilon$ :

$$
\sigma=\varepsilon \cdot E
$$

where:

$E$ - modulus of longitudinal elasticity,

the value of the local curvature was determined from:

$$
\chi=\frac{\varepsilon}{y}
$$

where:

$\varepsilon$ - the strain of given section fibres,

$y$ - the distance between the strain measuring point and the neutral axis of the section.

Hence, the local (momentary) stiffness of the beam was estimated to be:

$$
B=\frac{M}{\chi}
$$

which was shown as a bending moment function in Fig. 10.
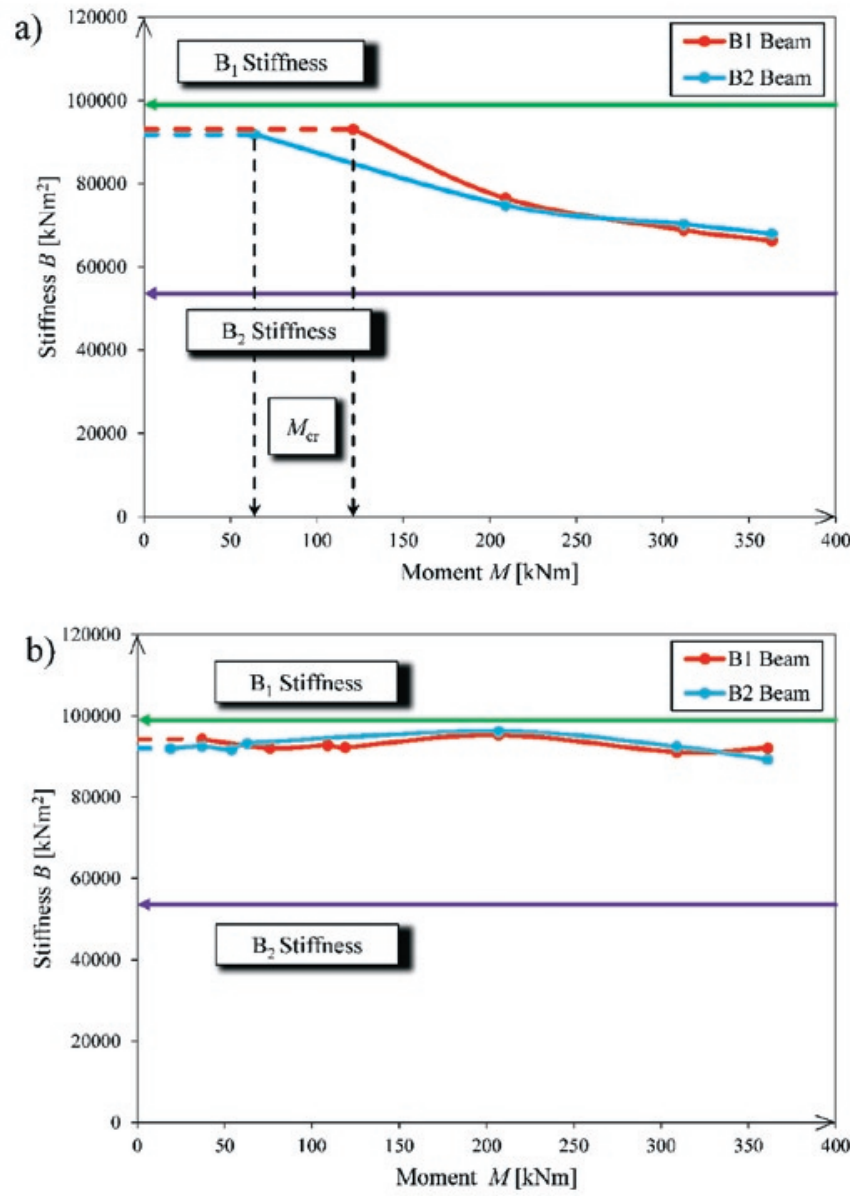

Fig. 10. Instantaneous stiffness of the test pieces: a) support section, b) span section

Apart from the actual measured values, the graphs also include values calculated with the assumption that the stiffness:

- is equal to the stiffness of the replacement steel section, in which the concrete section was replaced with an equivalent steel section $\left(B_{1}\right)$,

- is equal to the stiffness of the equivalent steel section (a profile and concrete slab reinforcement) $\left(B_{2}\right)$.

The analysis of the obtained results indicates that for elastic strain (the operating state of the analysed system), the effect of the nonlinearity of the $\sigma-\varepsilon$ concrete relationship on the stiffness of the composite sections with a compression concrete slab is insignificant (with a $2 \%$ slab reinforcement characterising the test pieces, this effect is negligible) and therefore they do not cause the redistribution of bending moments in the continuous beam.

For the sections with the slab in tension until the appearance of the first local crack, the local curvature (stiffness) of the beam is ap- 
proximately equal to the stiffness of the "full composite section", i.e. the stiffness including the interaction of the concrete slab and the reinforcement. A clear decrease in the stiffness was observed after the appearance of the first crack (sharp increase in the curvature). The relative stiffness of the beam in relation to the steel section decreased with an increase in the beam stress.

\subsubsection{Results of deflections (displacement)}

Beam deflection was measured at two points in the location where the external load was applied. In addition, vertical displacements readings were taken in the longitudinal beam axis, above each support. The comparison of the average values of the deflections obtained for each tested beam as a function of the applied force is shown in Fig. 11.
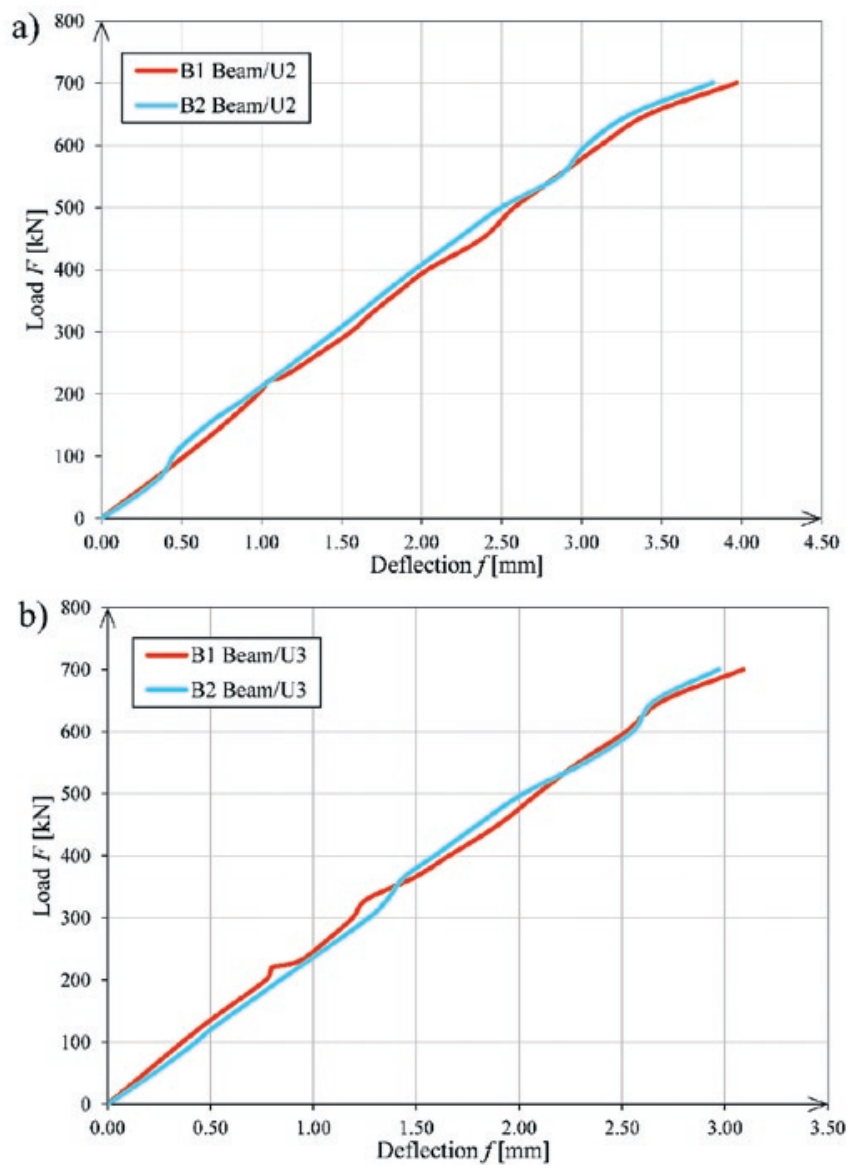

Fig. 11. Beam deflection in the location where the load was applied: a) span 1, b) $\operatorname{span} 2$

Based on the analysis of the steel girder displacement, it was found that the static balance paths showed a clear linear behaviour for the operating load. Additionally, it was observed during the tests that the formation of the subsequent cracks causes abnormal local curvatures and their rapid changes.

The experimental tests showed that because of the interaction of the concrete in tension with the reinforcement in the segments between the cracks, the average stiffness of the cracked segment takes the intermediate value between the calculated stiffness with the inclusion of the concrete and the steel and the stiffness of the section calculated with a complete omission of the interaction of the concrete. Also, much faster increases in the deflections than prior to cracking were observed. This means that omitting this phenomenon in the design practice so far resulted in a significant underestimation of the theoretical operating lifespan and the design stiffness of bridge structures.
Taking cracks into account during the design work is especially important in the case of precamber, but this problem applies to certain checks in the ultimate limit state, as well. One example is the fatigue analysis $[8,9]$. In addition, the tension stiffening effect, which causes a movement up the axis of inertia of a fully cracked support section of the composite beam in the fourth class, may reduce the reliability of the structure by changing the stress system in the web and the problems with the stability of the slender web.

\section{Numerical model of the tested composite beam}

Proper modelling of composite beams [14] subjected to operational interactions where the concrete slab is in tension is a difficult task which is more complex than the case of the compression slab [31]. This results, in large part, from the problems in estimating the stiffness of the reinforced concrete part of the element in tension, including the determination of interaction of the concrete in tension with the reinforcement [37]. In the analysis, this applies primarily to the estimation of:

- the moment that initiates the cracking process,

- the changes in the stiffness with the increasing stress of the section.

An additional problem in the numerical analysis of such a model is the method of introduction of the joining of the steel part and the concrete part of the section and the description of the damage mechanism of the concrete slab in tension $[15,42]$.

Due to the complexity of the issues under consideration, which apply, first and foremost, to the mechanics of concrete [11] and are related to the non-linearity of the problem, all computational tasks were performed in the Abaqus software [1], which makes it possible to include all non-linear effects (the Newton-Raphson incremental iterative method) affecting the results both qualitatively and quantitatively. There are several main sources of non-linearity, e.g. the physical nonlinearity, the geometric non-linearity or the non-linearity resulting from the boundary conditions that vary within the process. This paper focuses on the physical non-linearity that describes concrete. All the conducted numerical simulations include geometric non-linearities associated with large strains, as well. The non-linearity of the boundary conditions was also taken into account, which was associated with the contact, in particular.

\subsection{Assumptions of the numerical model}

Simplifications are an integral part of each computational model, especially numerical ones that approximate an actual structure. Hence, the numerical calculations used the following assumptions:

- the Concrete Damage Plasticity (CDP) model was used,

- the reinforced concrete transfers tensile stress even after cracking [37],

- the steel meets the requirements of a linear-elastic-plastic material,

- the reinforcement (longitudinal bars and stirrups) were modelled in a discreet way by introducing it as elements embedded in the host-type beam slab,

- the same load was used as in the experimental tests (two concentrated forces applied to the mesh nodes on the slab).

\subsection{Geometrical models}

Due to the nature of the structure being modelled, which consists of two different materials with clearly different geometries, the model had different types of finite elements that best described the components of the beam. Therefore, the individual parts were modelled using (Fig. 12):

- eight-node brick elements with reduced integration (C3D8R): the concrete slab, 


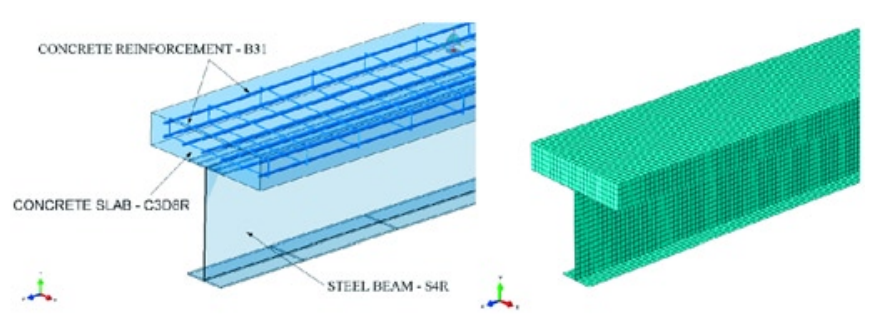

Fig. 12. FEM model and discretisation of the beam being analysed

- four-node shell elements with reduced integration (S4R): the rolled steel I-beam,

- two-node linear beam elements (B31): the primary reinforcement bars and stirrups.

Joining of the concrete slab with the upper flange of the steel beam was varied, depending on the distribution of bending moments along the length of the beam (Fig. 3). Hence, the joining was modelled in the tension zone as a discrete connection representing the occurrence of rigid connectors in the elements subjected to the laboratory tests. Special elements were used for this purpose: the so-called connectors, which make it possible to physically connect two different deformable elements in a discreet way (point to point) while representing the type of joints and the behaviour of the fasteners. The used beam connection type provided a rigid connection (with infinite bending stiffness and flexural rigidity) between two nodes, out of which one was a top steel flange mesh node and the other was a concrete slab mesh node (Fig. 13). Additionally, the contact surfaces between the upper flange of the steel beam and the concrete slab were defined, adopting the friction coefficient $\mu=0.5$ [15].
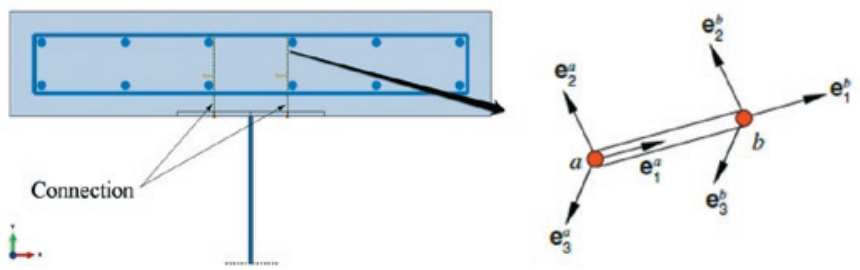

Fig. 13. View of the beam connection type being modelled

On the other hand, in the positive moment zones where the slab was compressed, the full joining of the upper surface of the steel beam with the lower surface of the reinforced concrete slab by means of a "continuous" (tie) connection was taken into account.

\subsection{Material models}

For representation in the numerical analyses of the behaviour of beams subjected to operating loads, it was necessary to describe the stress-strain relationship for the concrete in compression and tension [38] and the steel.

For modelling the concrete, the Concrete Damage Plasticity (CDP) model was used for the complex modelling of the concrete both in the compression and tension zone in the complex stress state $[1,4]$. This model includes combinations of non-associated plasticity with hardening and scalar isotropic elastic damage to determine irreversible changes that occurred during the process of cyclic loading and unloading (Fig.14). The CDP model is based on the brittle-plastic degradation model created by Lubliner et al. [21, 25] and later perfected by Lee and Fenves [18].

To describe the CDP concrete model, some material parameters had to be determined. Some of them were obtained from strength tests (Table 2) and some resulted from theoretical assumptions. The CDP model is described by [1]:

$\beta-$ the angle of internal friction of the concrete; the angle of the asymptote of the Drucker-Prager hyperbolic surface (as the surface of the yield potential) to the hydrostatic axis, measured in the meridional plane; according to [4], the parameter is adopted for the ordinary concrete, usually equal to $36^{\circ}$,

$\epsilon-$ the eccentricity of the yield potential; a small positive value that characterizes the approaching speed of the yield potential hyperbole to its asymptote; calculated as a quotient of the concrete tensile strength to compressive strength,

$f$ - the number determining the critical compressive stress quotient in the biaxial state to the critical compressive stress in the uniaxial state; this parameter is determined based on the Kupfer curve,

$K_{\mathrm{c}}$ - the parameter determining the shape of the surface of the yield potential on a deviatoric plane; the shape of the boundary surface in the deviatoric plane is not a circle but depends on the third invariant of the stress state; according to [1], this parameter is usually assumed to be 0.666 ,

$\mu$ - the viscosity parameter, which allows to slightly exceed the surface of the yield potential in some sufficiently small task steps (it is used for regularisation of constitutive equations); the idea of visco-plastic regulation is based on such a selection of the parameter $(\mu>0)$ that the ratio of the task time step to the value of $\mu$ approaches infinity.

Other parameters that define the CDP model were identified from uniaxial concrete compression tests. The isotropic hardening in compression, isotropic weakening and isotropic damage in tension were determined based on these tests.

The CDP model uses the concepts of isotropic elastic damage in combination with isotropic plasticity in tension and compression. It contains the combinations of non-associated plasticity with hardening and the scalar isotropic elastic damage to determine the irreversible changes that occurred during the process of loading. The model flow surface in the area of the biaxial compression is represented by the classic Drucker-Prager yield criterion.

The CDP model assumes that two main damage mechanisms are concrete cracking generated by tension and concrete crushing due to compression. The development of the flow surface is described by two variables $\bar{\varepsilon}_{\mathrm{c}}^{\mathrm{pl}}$ and $\bar{\varepsilon}_{\mathrm{t}}^{\mathrm{pl}}$ is related to the damage mechanisms, and more specifically to the increments of the effective plastic strains in compression and tension (Fig. 14):

$$
\bar{\varepsilon}_{\mathrm{c}}^{\mathrm{pl}}=\bar{\varepsilon}_{\mathrm{c}}^{\mathrm{in}}-\frac{d_{\mathrm{c}}}{\left(1-d_{\mathrm{c}}\right)} \cdot \frac{\sigma_{\mathrm{c}}}{E_{0}}
$$

$$
\bar{\varepsilon}_{\mathrm{t}}^{\mathrm{pl}}=\bar{\varepsilon}_{\mathrm{t}}^{\mathrm{ck}}-\frac{d_{\mathrm{t}}}{\left(1-d_{\mathrm{t}}\right)} \cdot \frac{\sigma_{\mathrm{t}}}{E_{0}}
$$

where:

$$
\begin{aligned}
& \bar{\varepsilon}_{\mathrm{c}}^{\mathrm{in}}-\text { the inelastic strain of the compressed concrete, } \\
& \bar{\varepsilon}_{\mathrm{t}}^{\mathrm{ck}}-\text { cracking strain, } \\
& \sigma_{\mathrm{c}}-\text { compressive stresses in the concrete, } \\
& \sigma_{\mathrm{t}}-\text { tensile stresses in the concrete. } \\
& E_{0}-\text { the initial modulus of elasticity of the undamaged } \\
& \text { concrete. }
\end{aligned}
$$

These variables control the development of the flow surface and the development of the degradation of the elastic stiffness of the material. The process of reducing the stiffness of the material, known as the elastic degradation, starts when the stress path reaches the yield 
surface. The elastic degradation of the concrete is determined by two variables of the scalar stiffness degradation $d_{\mathrm{c}}$ (compression):

$$
d_{\mathrm{c}}=d_{\mathrm{c}}\left(\bar{\varepsilon}_{\mathrm{c}}^{\mathrm{pl}}, f_{\mathrm{i}}\right) \text { gdy } 0 \leq d_{\mathrm{c}} \leq 1,
$$

and $d_{\mathrm{t}}$ (tension):

$$
d_{\mathrm{t}}=d_{\mathrm{t}}\left(\bar{\varepsilon}_{\mathrm{t}}^{\mathrm{pl}}, f_{\mathrm{i}}\right) \text { gdy } 0 \leq d_{\mathrm{t}} \leq 1 \text {, }
$$

which are non-decreasing functions of the plastic strain (Fig. 14). The degradation variables take the value from 0 (in the case of undamaged material) to 1 (which corresponds to the total loss of the ability to transfer stress.

On the other hand, the steel was modelled as a linear-elastic-plastic body with parameters specified in Table 1. During the laboratory tests, there was no loss of geometric stability in the adopted range of operating loads. In addition, the preliminary analyses of the behaviour of the test piece showed that there was no need to define the plastic hardening of the material.

In addition, this elastic-plastic body model is good at reproducing the behaviour of the ordinary steel and is most commonly used in the classical theory of plasticity and for the calculation of the plastic limit load.

The problems related to obtaining the convergence of the solution caused by the non-linearity of the material model was solved by viscosity stabilisation. The size of the load increment was also reduced $(0.01-1 \mathrm{E}-12)$ and the maximum number of the load steps (max. 12000) was increased when solving the task using the Newton-Raphson approach. The selection of the $\mu$ parameter was made iteratively

a)

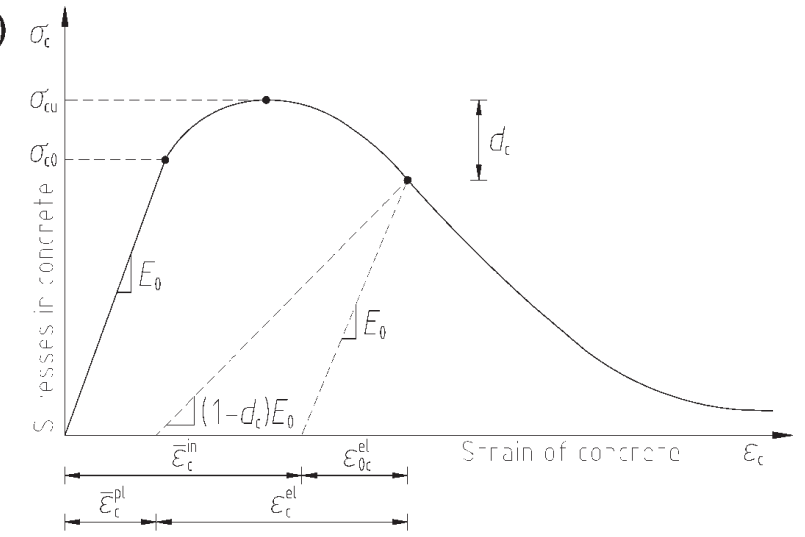

b)

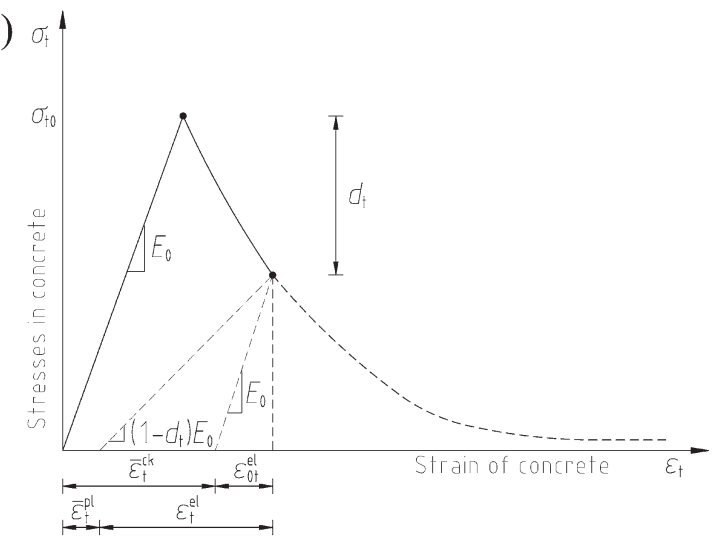

Fig. 14. Physical laws of concrete: a) compression, b) tension after analysing the size of its impact on the results of the task. Finally, $\mu=0.0001$ was adopted, allowing to solve the task in more than 1200 load increments formed in approx. 4000 iterations. The analysis of the behaviour of the test piece shows that such a value of the viscosity parameter makes it possible to reach a compromise between the computational magnitude of the tasks and the accuracy of the obtained results.

\subsection{Results of the numerical analyses}

The correctness of the FEM model assumptions was verified by comparing graphically specified operating parameters obtained from the numerical analyses with the experimental test results and also for the picture of the damage - in the form of data generated directly on finite elements, without averaging the data.

The comparison of the results was performed in selected sections and measuring points as shown in Fig. 4.

\subsubsection{Picture of the damage of the slab in tension}

Identification of the slab cracking was done on the basis of the analysis of the maps of the damage defined by the changes in the size of the DAMAGET parameter, i.e. the degradation of stiffness $d_{t}$, which depicts the material damage.

It should be remembered that the CDP material model does not enable the formation of cracks in a discreet way taking into account the material spalling (its losses). It results only in the gradual exclusion of finite elements from the interaction. In this way, their "bonding" occurs, as well as their further involvement in the transfer of strain onto the adjacent elements. This imperfection has no material impact on the behaviour of the whole test piece (static equilibrium path convergence was observed - Fig. 17).

The damage maps, defined by the $d_{\mathrm{t}}$ parameter, presented in Fig. 15 can be identified with the spots where cracks appeared in the concrete slabs of the tested composite beams. The picture of the damage obtained in the numerical analysis corresponds qualitatively to the picture of the distribution of cracks obtained during the experimental tests (Fig. 16).

The analysis of the damage maps defined by the $d_{\mathrm{t}}$ parameter also allows tracing the process of the formation and development of cracks with the increasing model load. In the case of the analysed beam, the first damage to the slab concrete appeared in the support axis, with the load causing tension in the concrete that was equal to the tensile strength of the concrete. In the initial phase, as the load continued to be increased, more cracks began to appear simultaneously on both sides of the support, spreading towards the centre of the span. The subsequent increase in the load caused the density of the damage zones to increase (cracks). A similar phenomenon was observed during the empirical studies.

\subsubsection{Analysis of the displacement and distribution of normal stress}

The verification of the numerical model was carried out by the juxtaposition of the obtained displacements of the tested beams and the numerical model (Fig. 17), as well as the stress distribution in the tested beams and in the numerical model (Fig. 18, Fig. 19).

The chart also shows that the difference between the beam stiffness in the experiment and the stiffness of the numerical model are similar to each other. This confirms the correctness of the selection of $d$ degradation variables ( $d_{\mathrm{t}}$, in particular) in the concrete model. It also indicates that for continuous beams in which there are zones with a slab in tension, a good representation is provided by the joining that uses a concrete slab spot connection with the steel girder, i.e. the joining model that faithfully represents the actual joining. However, in the zones where the concrete slab is compressed, the better representation 


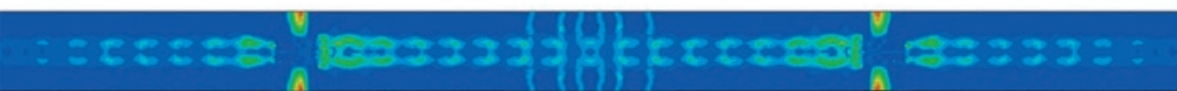

$\stackrel{\uparrow}{\uparrow}$

Fig. 15. The final picture of the material damage caused by the maximum external load (top view of the slab): stiffness degradationsection

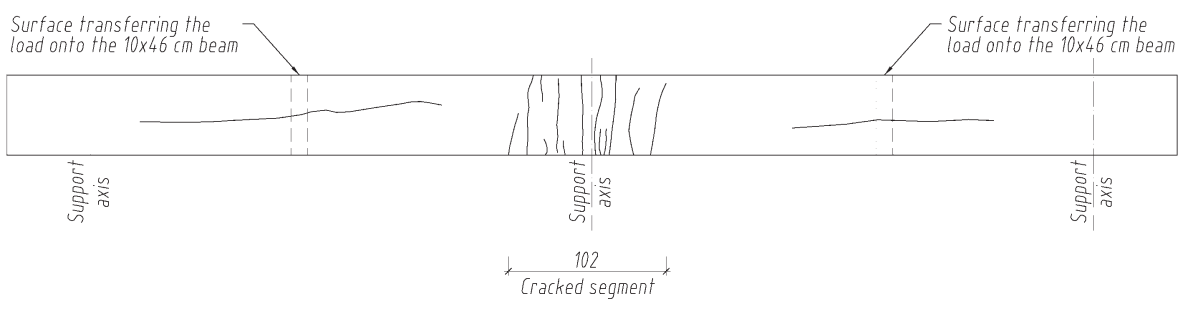

Fig. 16. Final picture of the tested beam slab top cracking of the behaviour of the tested beam can be obtained by using the full joining with the "continuous" connection [15].

The comparative analysis also indicates a good compatibility of the obtained results of the experimental and numerical studies and the general compatibility of the computational model with the assumption related to the material strength hypotheses and the adopted durability criteria.

The built numerical model may be used as a very effective tool for modelling complex structures for composite bridges (both road and rail bridges) which is closer to reality and may considerably improve the design process. In addition, it makes it possible to search for innovative design solutions, especially considering that the construction industry should expect soon the emergence of new forms of composite structures with a significant use of concrete in the composite section, where the issue of modelling the cracks and their impact on the operating lifespan and the performance characteristics will be very important.
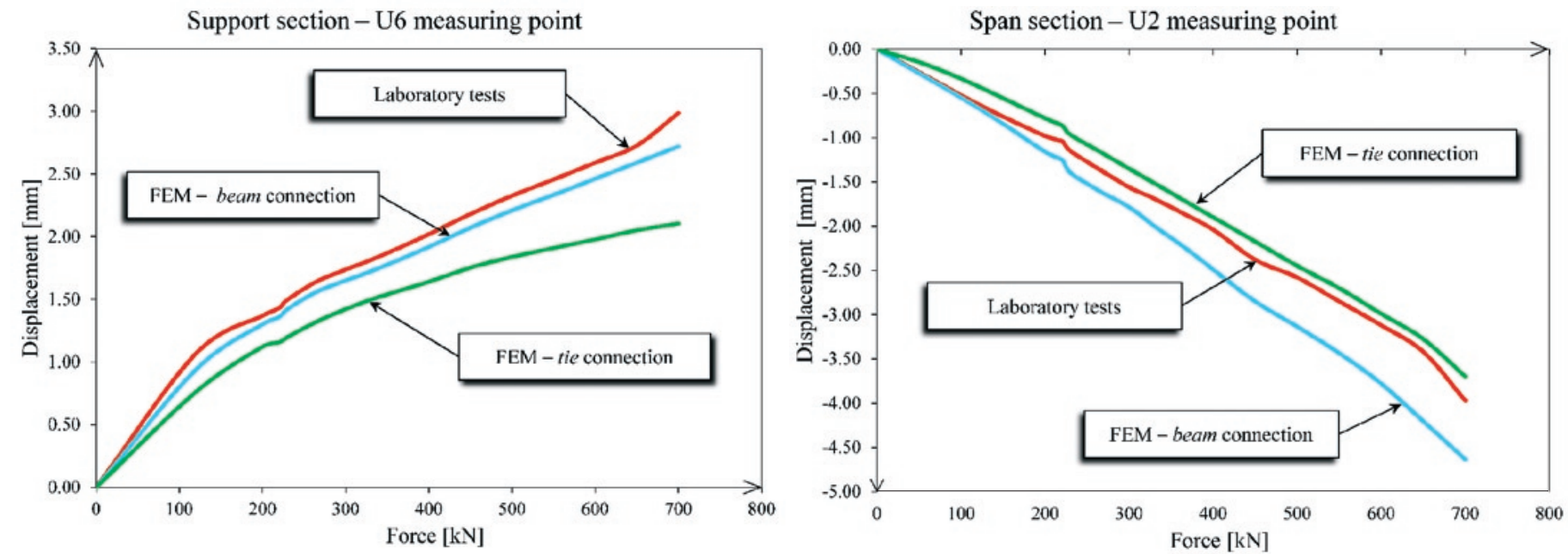

Fig. 17. Comparison of the vertical beam displacements measured and calculated with different methods of modelling the joining
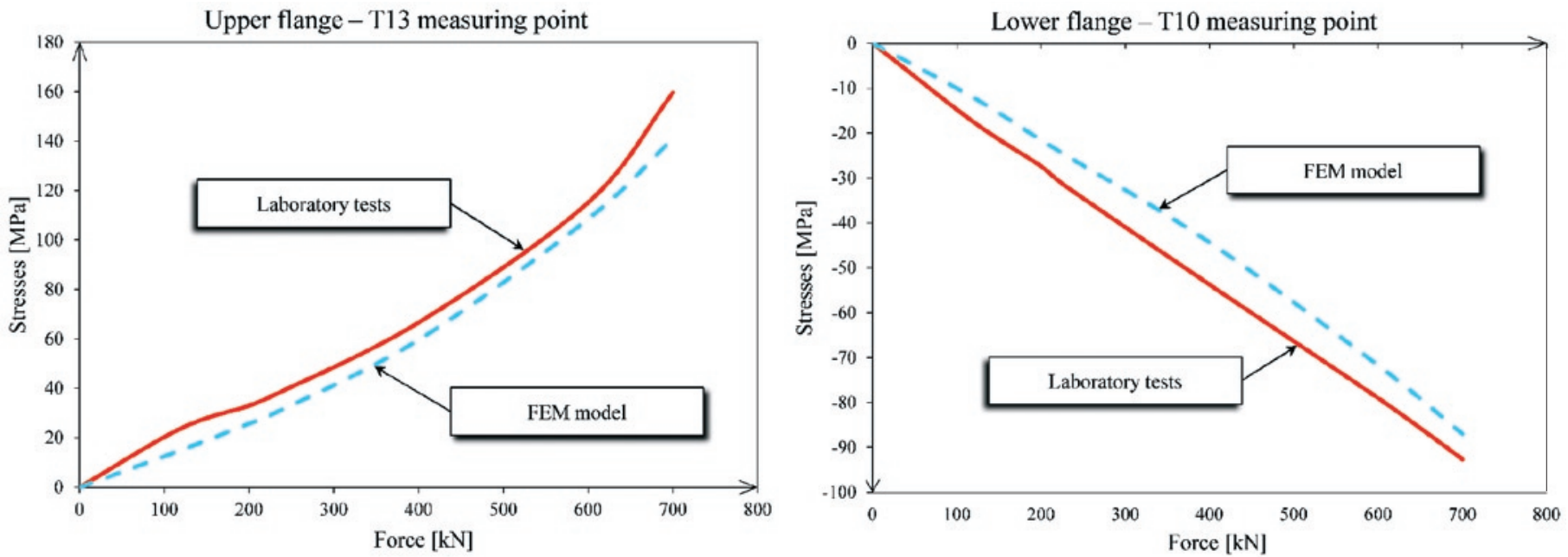

Fig. 18. Comparison of the stress magnitude of the steel beam in the support section-discrete connection 


\section{Conclusion}

Currently, the stage of dimensioning statically indeterminate composite structures does not take into account the effect of the stiffness of concrete in tension (with cracking). One can say that it is a great wastefulness that consequently affects the erroneous estimation of the operating lifespan of the structure. The conducted experimental studies and computer simulations showed that taking into account the stiffness of the concrete for segments between the cracks is an approach to structure serviceability assessment that is not only modern but also close to the reality. The actual stiffness of the composite sections is about $10 \%$ greater than the stiffness calculated in accordance with the current engineering practices [22]. It suggests that the operating lifespan of the composite bridges with continuous static systems built so far has been undervalued. This results in an unnecessarily increased use of the structural and reinforcement steel.

The results of the studies make it possible to formulate the following conclusions:

- The actual position of the neutral axis of the composite section is located between the designated axes of the crack and non-cracked section. When new cracks appear, the neutral axis moves towards the neutral axis of the section with stabilised cracking. The spacing of the cracks depends on the distribution of the strain in the tension zone, which is significantly impacted by the position of the neutral axis.

- The stiffness of the composite beams including a slab in tension is practically constant until cracking and is approximately equal to the stiffness calculated with the assumption of the full codeformability of the steel and concrete parts. A clear decrease in the stiffness was observed upon the appearance of the first cracks. The changes in the stiffness in the section with the compression slab for elastic strain (for operating loads) are small while the load is increasing and do not cause the redistribution of the bending moments in the continuous beam.
- A detailed analysis of the composite concrete and the steel beams with a slab in tension (with the specification of the full static equilibrium path) can be carried out using the finite element method and the non-linear structural analysis algorithms. The studies determining the material characteristics used to create the individual elements of the beams are necessary for their correct modelling.

- Proper description of the concrete in tension, which takes into account its behaviour after cracking, has a significant impact on the compatibility of the results of the numerical analyses with the results of empirical tests. The introduction of the damage parameter for the concrete in tension $\left(d_{\mathrm{t}}\right)$ into the analysis makes it possible to analyse the slab cracking on each beam load level.

- One of the important aspects of modelling the composite steel and concrete beam is the adoption of the joining model - the method in which the concrete slab is connected with the steel girder. The method applied for the numerical modelling of the concrete slab in tension and its connection to the steel beam allows to precisely determine the level of strain and damage to the slab in tension at each composite beam load level. In the case of the continuous beams, it is necessary to diversify the modelling of the joining of the steel and concrete parts, depending on the distribution of bending moments along the length of the beam.

\section{Acknowledgements}

The author would like to thank the Gotowski Budownictwo Komunikacyjne i Przemystowe Sp. z o.o. company for providing the testing materials free of charge. Laboratory studies were co-funded under the statutory measures of the Ministry of Science and Higher Education No. S-50/B/2012 and Młoda Kadra 2013.

\section{References}

1. Abaqus User's Manual. Version 6.12, USA: Dassault Systèmes Simulia Corp, 2012.

2. Bavan M., Baharom S., Mutalib A.A., Osman S.A. Numerical prediction of composite beam subjected to combined negative bending and axial tension. Journal of Engineering Science and Technology 2013; 8(4): 428-447.

3. Biegus A., Lorenc W.: Development of shear connections in steel-concrete composite structures. Civil and Environmental Engineering Reports 2014, 15(4): 23-32.

4. Chen W.F. Plasticity in reinforced concrete. NYC: McGraw-Hill Book Company, 1982.

5. Chen S., Jia Y. Required and available moment redistribution of continuous steel-concrete composite beams. Journal of Constructional Steel Research 2008; 64(2): 167-175, http://dx.doi.org/10.1016/j.jcsr.2007.05.006.

6. Chen S., Jia Y., Wang X. Experimental study of moment redistribution and load carrying capacity of externally prestressed continuous composite beams. Structural Engineering and Mechanics 2009; 31(5): 605-619, http://dx.doi.org/10.12989/sem.2009.31.5.605.

7. Czudek H., Wysokowski A. Twałość mostów drogowych. Warsaw: Wydawnictwo Komunikacji i Łączności, 2005.

8. Fan J., Nie J., Li Q., Wang H. Long-term behaviour of composite beams under positive and negative bending. I: Experimental study. Journal of Structural Engineering 2010; 136(7): 849-857, http://dx.doi.org/10.1061/(ASCE)ST.1943-541X.0000175.

9. Fan J., Nie J., Li Q., Wang H. Long-term behaviour of composite beams under positive and negative bending. II: Analytical. Journal of Structural Engineering 2010; 136(7): 858-865, http://dx.doi.org/10.1061/(ASCE)ST.1943-541X.0000176.

10. Gara F., Ranzi G., Leoni G. Design Expressions for the Effective Width of Composite Steel-Concrete Members. IABSE Symposium Report, IABSE Madrid Symposium: Engineering for Progress, Nature and People 2014; 161-168, http://dx.doi.org/10.2749/222137814814027701.

11. Godycki - Ćwirko T. Mechanika betonu. Warsaw: Arkady, 1980.

12. Gómez Navarro M., Lebet J.-P. Concrete cracking in composite bridges: tests, models and design proposals. Structural Engineering International 2001; 11(3): 184 190, http://dx.doi.org/10.2749/101686601780346922.

13. He J., Liu Y., Chen A., Yoda T. Experimental study on inelastic mechanical behaviour of composite girders under hogging moment. Journal of Constructional Steel Research 2010; 66: 37-52, http://dx.doi.org/10.1016/j.jcsr.2009.07.005.

14. Hernández H., Bonilla J., Rodríguez G. Study of the behaviour of composite beams made of concrete and steel by using numerical simulation. Revista ingeniería de construcción 2014; 29(1): 5-21, http://dx.doi.org/10.4067/S0718-50732014000100001.

15. Jankowiak I., Madaj A. Stalowo-betonowy dźwigar zespolony z rozciąganą płytą betonową. Inżynieria i Budownictwo 2011 ; 12 : $667-671$.

16. Johnson R. P. Composite Structures of Steel and Concrete: Beams, Slabs, Columns, and Frames for Buildings. Malden: Third Edition, Blackwell Publishing, 2008. 
17. Lebet J.-P, Gómez Navarro M.G. Influence of Concrete Cracking on Composite Bridge Behaviour. Composite Construction in Steel and Concrete V 2006: 77-86.

18. Lee J., Fenves G.L. Plastic-damage model for cyclic loading of concrete structures. Journal of Engineering Mechanics 1998; 124(8): 892900, http://dx.doi.org/10.1061/(ASCE)0733-9399(1998)124:8(892).

19. Lin W., Yoda T. Experimental and numerical study on mechanical behaviour of composite girders under hogging moment. Advanced Steel Construction an International Journal. 2013; 9(4): 280-304.

20. Lin W., Yoda T., Taniguchi N., He Y. Mechanical Performance of Steel-Concrete Composite Beams Subjected to a Hogging Moment. Journal of Structural Engineering 2014; 140(1): 04013031/1-04013031/11.

21. Lubliner J., Oliver J., Oller S., Onate E. A plastic-damage model for concrete. International Journal of Solids and Structures 1989; 25(3): 299-326, http://dx.doi.org/10.1016/0020-7683(89)90050-4.

22. Łagoda M., Śledziewski K. Analiza mostowej konstrukcji stalowo-betonowej z płytą rozciąganą. Materiały Budowlane 2014; 4: 55-58.

23. Łagoda M., Śledziewski K. Operation of a steel-concrete composite beam considering slab cracking. Budownictwo i Architektura 2014; 13(2): 265-274

24. Nakamura S., Momiyama Y., Hosaka T., Homma K. New technologies of steel/concrete composite bridges. Journal of Constructional Steel Research 2002; 58(1): 99-130, http://dx.doi.org/10.1016/S0143-974X(01)00030-X.

25. Oller S., Onate E, Oliver J., Lubliner J. Finite element nonlinear analysis of concrete structures using a "Plastic-Damage model". Engineering Fracture Mechanics 1990; 35(1/2/3): 219-231.

26. EN 1990:2002, Eurocode: Basic of structural design.

27. EN 1992-1-1:2004, Eurocode 2: Design of concrete structures, Part 1-1: General rules and rules for buildings.

28. EN 1994-2:2005, Eurocode 4: Design of composite steel and concrete structures, Part 2: General rules and rules for bridges.

29. EN 12390-3:2009, Testing hardened concrete, Part 3: Compressive strength of test specimens.

30. EN 12390-6:2009, Testing hardened concrete, Część 6: Tensile splitting strength of test specimens.

31. Prakash A., Anandavalli N., Madheswaran C.K., Rajasankar J., Laksh-manan N. Three Dimensional FE Model of Stud Connected SteelConcrete Composite Girders Subjected to Monotonic Loading. International Journal of Mechanics and Applications 2011; 1(1): 1-11.

32. Ryu H.-K., Chang S.-U., Kim Y.-J., Kim B.-S. Crack control of a steel and concrete composite plate girder with prefabricated slabs under hogging moments. Engineering Structures 2005; 27(11):1613-1624, http://dx.doi.org/10.1016/j.engstruct.2005.05.015.

33. Ryu H.-K., Kim Y.-J., Chang S.-P. Crack Control of a Continuous Composite Two-girder Bridge with Prefabricated Slabs under Static and Fatigue Loads. Engineering Structures 2007; 29(6): 851-864, http://dx.doi.org/10.1016/j.engstruct.2006.06.021.

34. Sen R., Liby L., Mullins G. Strengthening steel bridge sections using CFRP laminates. Composites Part B: Engineering 2001; 32(4): 309322, http://dx.doi.org/10.1016/S1359-8368(01)00006-3.

35. Shin H.-S. Influence of tensile behaviour of slab on the structural behaviour of shear connection in composite beam subjected to hogging moment. International Journal of Engineering Research and Development 2015; 11(9): 6-15.

36. Szcześniak W., Karaś S. Durability of bridge objects. Logistyka 2015; 4: 5965-5973.

37. Śledziewski K. Operation of a steel-concrete composite beam considering slab cracking. Doctoral dissertation. Lublin: Lublin University of Technology, 2016.

38. Tejchman J., Bobiński J. Continuous and Discontinuous Modelling of Fracture in Concrete Using FEM. Berlin-Heidelberg: Springer-Verlag, 2013, http://dx.doi.org/10.1007/978-3-642-28463-2.

39. Ugural A. C., Fenster S. K. Advanced Mechanics of Materials and Applied Elasticity. Fifth Edition. New Jersey: Prentice Hall, 2011.

40. Vayas I., Iliopoulos A. Design of Steel-Concrete Composite Bridges to Eurocodes. Boca Raton: CRC Press, 2014.

41. Woyciechowski P., Adamczewski G. Kształtowanie trwałości betonowych konstrukcji mostowych. Warsaw: Wydawnictwo Polskiej Izby Inżynierów Budownictwa, 2014.

42. Wróblewski T., Pełka-Sawenko A., Abramowicz M., Berczyński S. Modeling and analysis of free vibration of steel-concrete composite beams by finite element method. Advances in Manufacturing Science and Technology 2012; 36(4): 85-96.

Krzysztof ŚLEDZIEWSKI

Department of Road and Bridge

Lublin University of Technology

ul. Nadbystrzycka 40, 20-618 Lublin, Poland

E-mail:k.sledziewski@pollub.pl 